\title{
SOVEREIGNTY OF STATES IN THE POST COLD WAR ERA: IMPLICATIONS FOR SUB-SAHARAN AFRICA
}

\author{
Thomas Jørgenson \\ Department of Development Research, \\ Danish Institute for International Studies
}

\section{Introduction}

The United Nations (UN) was founded to 'to save succeeding generations from the scourge of war'. ${ }^{1}$ However, the post-independence history of sub-Saharan Africa has demonstrated that the international community, or lack of an international society, has so far been unable to protect the African continent from this 'scourge', or indeed from itself. A number of reasons may be suggested for this, including the organisation of the international community into a number of sovereign independent states, the inability of some of these territorial sovereignties to act and function as states, the formal political and economic crisis and marginalisation of especially sub-Saharan Africa, and finally the history of the continent. Accordingly, this article has two major objectives. The article will illustrate how state failure and intrastate asymmetric warfare alters and undermines the Westphalian concept of state in subSaharan Africa. Furthermore it attempts to show that the way in which the concept of 'national sovereignty' is understood is changing, and that this might have instrumental implications for future interstate relations in sub-Saharan Africa.

The background to the above mentioned changes is to be found partly in the humanitarian approach that gained momentum in the post-Cold War period and, despite the setbacks in the 1990's in Somalia, Rwanda and Bosnia, has become increasingly influential in how inter-state relations is perceived and understood. The international community is not simply anarchic, since there are limits to anarchy. Rules and norms have become increasingly influential, not just among first-world states, but also, if gradually, among third-world states, as well through aid

\footnotetext{
Preamble to the UN Charter.
} 
conditionalities and 'democracy by force'. ${ }^{2}$ The international regulations that justify the use of force seem to be changing and even being extended to include, for instance, regime change. The custom of inter-state relations since the peace of Westphalia in 1648 is being pressured by new practices by the most powerful states in the international system, that is primarily the United States of America and its allies in the war on terror. Furthermore, the basic norm in interstate relations, namely the acceptance of national sovereignty - that is, of non-interference in domestic affairs - seem to be changing because of the inability of the post-colonial states to live up to the reciprocity that interstate relations imply. ${ }^{3}$ The international community is furthermore to be perceived as being divided into a liberal and a nonliberal zone, where the states in the non-liberal zone has to 'qualify' to be accepted into the liberal zone, and thereby get access to the political and economic advantages this zone provides. This is not a formal institutionalised system however, the international community operates along those lines in practice. International society is as argued by Buzan, not to be understood as an international society comprising the whole world, but operates as a limited 'society of states', that is the states within the liberal zone. ${ }^{4}$ This article attempt to illustrate that those states in sub-Saharan Africa outside this 'society of states' do not de facto have the same national sovereignty rights, because sovereignty in the contemporary world order is not just about authority, but as much about responsibility.

The UN has expanded its understanding of security to include human security and deposed authoritarian leaders are increasingly being faced with the risk of being tried for the crimes committed while in power. This means that the focus has been expanded from 'state security' or even regime security to a focus on the broad 'security of the individual human being'. However, the increasing significance of these international norms does not go uncontested, and a dispute appears to have broken out over the direction that future interstate relations should take.

For sub-Saharan Africa, the implications of this can already be seen in a softer version. One example is the disputed imposition of sanctions on Zimbabwe, a country where first-world normative standards are colliding with the African concept of solidarity and adherence to the importance of sovereignty and regime

Karen von Hippel uses this term in her book of the same title, Democracy by Force, to describe how the US government launched a nation-building, i.e. state building, project after a military operation in the 1990s. See K. von Hippel, Democracy by Force, pp. 3ff.

G. Sørensen, The Global Polity and Changes in Statehood, p. 49.

For further reading on the concept of the liberal/non-liberal zone and on the notion International Society and Society of States see for instance, B. Buzan, From International to World Society, and H. Bull, The Anarchical Society. 
security. The wars in Afghanistan and in Iraq 2003 are in each case examples of the tougher line that the first world is taking over among other things introducing liberal democracy by force. The experiences since the end of the 1990's suggest that military intervention will increasingly be accepted as a tool of policy that may override the principle of sovereignty, that is the sovereignty of the states in the nonliberal zone. The UN Secretary General Kofi Annan stated already in 1998 in relation to that;

'For the UN there is no higher goal, no deeper commitment and no greater ambition than preventing armed conflict. The prevention of conflict begins and ends with the promotion of human security and human development. Ensuring human security is, in the broadest sense, the cardinal mission of the UN. ${ }^{5}$

This has to be compared with the UN Charters article 2 which stipulates that;

'All Members shall refrain in their international relations from the threat or use of force against the territorial integrity or political independence of any state, or in any other manner inconsistent with the Purposes of the United Nations. [...] 'Nothing contained in the present Charter shall authorize the United Nations to intervene in matters which are essentially within the domestic jurisdiction of any state or shall require the Members to submit such matters to settlement under the present Charter; but this principle shall not prejudice the application of enforcement measures under Chapter Vll. ${ }^{6}$

The change which became apparent during the 1990's was in the perception of what constituted the 'domestic jurisdiction of the state'. Kofi Annan's focus on 'human security' meant that issues such as human rights abuse which previously has been considered within the domain of the state, was increasingly considered to be grounds enough for the UN Security Council to act, though it has so fare not been the formal grounds for the mandates provided.

\section{The challenge to the states in sub-Saharan Africa in the post-Cold War era}

The number of conflicts in sub-Saharan Africa during the 1990's have been relatively constant. However, the conflicts increasingly became of an intrastate nature. ${ }^{7}$ At the same time resources available to conflict-resolution through the international community was falling significantly. The traditionally weak African

\footnotetext{
$5 \quad$ K. Annan, The Causes of Conflict and the Promotion of Durable Peace and Sustainable Development in Africa. Report of the Secretary-General, 1998, paragraph 2.

UN Charter, Article 2.

P. Wallensteen \& M. Sollenberg, 'Armed Conflict, 1989-2000', Journal of Peace Research, vol. 38, no. 5 (September 2001), pp. 629-644.
} 
state redistributing government resources in a patron-client pattern ${ }^{8}$ lost a great part of its overseas funding. William Reno argues, that post Cold War Africa features new state structures that are vulnerable, because of the lack of traditional overseas support and the harsh Bretton Wood structural adjustment programmes (SAPs), and leaves the African states open to 'warlordism' and insecurity. He further stresses that African states with close ties to world market economy further enhance the above mentioned danger and bring the weak state closer to be controlled by warlord rulers and there allies. ${ }^{9}$ The warlords are filling a power vacuum, left by the weak states inability and lack of military capacity to address security threats and the states monopoly on the legitimate use of violent force. Furthermore the warlord leaders often uses de jure sovereignty to attract outside support, that is both international business interest and political support from other states, in there struggle with domestic competitors for power. ${ }^{10}$

In sub-Saharan Africa 'elite accommodation' has been the way in which the ruler secured his sovereign authority over the territory and its population. By making informal deals with individuals exercising authority in their own right within the territory, the ruler secured his position and relative stability. ${ }^{11}$ The SAPs and the end of the Cold Wars penetration into sub-Saharan Africa removed the financial basis for these type of power structures, and a struggle for authority and control over the territory started. The semblance of sovereignty was gone. ${ }^{12}$ It was Charles Tilly that once argued that there is an analogy between war and state formation, and though less successful, organised crime too. ${ }^{13} \mathrm{He}$ also claimed that war makes states, and that mercantile capitalism in Renaissance Europe and state-making reinforced each other. ${ }^{14}$ The traditional equation in International Relations theory was based on a notion that war had to be analysed because it was a part of the relations between states. The domestic political picture and logic was based on the degree of external interference. However, today this assumption must be reversed because most wars since the end of the Second World War have not been fought between states, but

For further reading on 'clientilism', see for instance J-F. Bayard, The State in Africa The Politics of the Belly.

W. Reno, Warlord Politics and African States, pp. $223 \mathrm{ff}$.

W. Reno, Warlord Politics and African States, pp. 222.

For further reading on the concept of 'elite accommodation' see J-F. Bayart, The State in Africa - The Politics of the Belly, pp. $150 \mathrm{ff}$

12 W. Reno, Warlord Politics and African States, p. 2

Violence is not just a means to an end. It draws and transforms the passive observer into an active participant in the violent uprising against the oppressor, transforming man from a passive object into an active subject of political participation. K.J. Holsti, The State, War, and the State of War, p. 119.

14 C. Tilly, 'War Making and State Making as Organized Crime', in Evans et al, Bringing the State Back In, p. 170. 
within them. This creates a problem for the state-building process because wars have historically been seen as a necessary and integral part of state formation. To understand interstate relations, one must focus on the domestic politics of individual states. The reasons for the present-day conflicts are to be found in the nature of the new states. ${ }^{15}$ Interstate wars have turned out to be the exclusive domain of small and medium-size powers like Iraq and Israel and Ethiopia and Eritrea. The exception seems to be when the small and medium-size states dare to challenge the position of the big powers, as with Iraq in 2003. American President, George W. Bush, often refers to a distinction between civilised and non-civilised states in his speeches. His rhetorical usage of sentences like 'we in the civilised world' and 'you are either with us or against us' gives an insight into a way of thinking and understanding of the structure of the world within government circles in the White House. It shows that the American administration sees the 'civilised world' as a place requiring particular qualifications for states to become members. States therefore do not possess the same sorts of legitimacy. In addition, the civilised world sees it as its right and duty to act against 'uncivilised states', despite international law and treaties.

The sources of present and future wars seem to lie in the very different experiences of European and third-world countries of state birth and formation. ${ }^{16}$ According to Tilly state-making processes can be divided into:

1. a period of anarchy and plunder;

2. a stage in which tribute-takers attracted clients and established monopolies by struggling to create exclusive, substantial states;

3. a stage in which merchants and landlords began to gain more from protection ${ }^{17}$ rents than governors did from tribute; and

4. a period (fairly recent) in which technological changes surpassed protection rents as sources of profit for entrepreneurs. ${ }^{18}$

It can be argued that African states in the post-independence period have reached the fourth stage without going through any of the three earlier stages, only, in some instances, to go into reverse later and end up in stage one.

\footnotetext{
15 K.J. Holsti, The State, War, and the State of War, p. 15.

16 K.J. Holsti, The State, War, and the State of War, p. 40

17 The term 'protection' has different meanings: a positive meaning of being protected from evil by a stronger, well-disposed friend; and a negative meaning of being forced to by protection from a powerful strongman. C. Tilly, 'War Making and State Making as Organized Crime', in Evans et al, Bringing the State Back In, pp. 170.

18 C. Tilly, 'War Making and State Making as Organized Crime', in Evans et al, Bringing the State Back In, p. 176-177.
} 


\section{Asymmetric warfare and wars of 'newish' kind}

The events in Rwanda in 1994 actualised this debate, because neither the international community nor the Organisation of African Unity (OAU) reacted at the time by attempting to stop the atrocities, despite their awareness of the seriousness of the events. This lack of response started a discussion in sub-Saharan Africa on what could be done in the event of a Rwanda-like situation arising in the future. The use of violence beyond the UN comfort zone, that is substantial use of coercive means, featured in some of the options that were put forward. One of the problems facing both the international community and the African continent has been that conflicts in sub-Saharan Africa have usually been characterised by an 'asymmetric' type of warfare. This means that the traditional national or even regional focus on 'security' are insufficient means in responding to this type of conflict. Conflict in contemporary sub-Saharan Africa is typically low-intensity and intrastate in kind, as in Holsti's notion of 'wars of the third kind'. ${ }^{19}$

In the aftermath of 11 September 2001, a new term has evolved referring to the argument that a new, third-generation conflict is developing in sub-Saharan Africa, characterised as being transnational and dominated by international networks, sometimes with global terror as a goal. A British expert on Sierra Leone, Professor Paul Richards, stated at a conference in Copenhagen that these networks often were dominated by youth, and an ideological struggle against perceived injustice. ${ }^{20}$ However, the motivation might differ between for instance Islamist terrorists on the Afghanistan/Pakistan border and for instance Revolutionary United Front (RUF) rebels in Sierra Leone, but the way they organize and the means of fighting have a lot of similarities. An individual state's response to this kind of global challenge will be insufficient, whether it is the fight against Islamist terrorists or warlords with dubious international financial connections. In this article the argument is that what is seen in sub-Saharan Africa is not the rise of a new type of conflict, but a continuation of the asymmetric network conflicts that have plagued, for instance, Sierra Leone during most of the 1990's. There seem to be a number of similarities between the reasons for taking up arms and how to organise then and now. This means that there are often no clearly demarcated front lines, and the dominant actors in the conflicts are often many in number. In other words, new rebel movements are developing and dying out all the time, demanding to be included and to be given say in diplomatic efforts to resolve the conflicts.

K.J. Holsti, The State, War, and the State of War, pp. 36ff.

Lecture given by Professor of Anthropology, Paul Richards, at the Centre for African Studies, Copenhagen, 7 February 2002. 
Even though many examples of this type of movement are only empty shells without any genuine content, these actors have managed to exploit the international media to draw attention to their existence. The RUF in Sierra Leone being an illustrative case of point. During the 1990s it became increasingly clear that this type of armed movements often do not have any real political or ideological objective. ${ }^{21}$ Rather, they are armed actors seeking a military goal and not armed militants with a political objective. This creates huge difficulties in settling a conflict because these types of actors often do not have any incentive in making peace if this will result in a loss of influence on their part: there is no peace dividend to be gained. ${ }^{22}$

There is thus a dichotomy between war as a form of social interaction and war as the domain of the state. The 'new wars' must be understood not just as a form of social breakdown and anarchic chaos, but as non-territorial network wars. ${ }^{23}$ During the Cold War international penetration in sub-Saharan Africa prolonged a number of conflicts because international support for the antagonists acted to maintain a military balance. ${ }^{24}$ After the end of the Cold War this support was withdrawn, leading to the peaceful conclusion of a number of conflicts. The lack of ability of predominately third-world states to control conflicts has led to lowintensity conflict (LIC), ${ }^{25}$ as seen in the long term conflicts in, for instance, Sudan, Colombia and Sri Lanka. These 'wars of the third kind' was coined to describe the new type of warfare which apparently emerged after the Second World War in states faced with institutional failure and collapse. Earlier, wars were conceived as being of limited length and having decisive battles. Wars of the third kind are characterised by having no declaration of war, no seasons for fighting, and often continuing for many years. ${ }^{26}$ It can be argued that Holsti's notion of 'war of the third kind' has a number of flaws in it and elements which do not stand up to scrutiny. Were traditional wars always limited in duration? One clear countervailing example is the Hundred Years War, which lasted for 116 years altogether. Holsti's argument that in wars of the third kind the parties engage in all-season fighting is also not universally applicable if one considers the conflict in Sudan and a number of other African conflicts, where seasonal fighting is still very much in evidence.

21 For that matter, the same can be said about a number of so-called governments that do not have any other political objective than staying in power for power's sake and to control resources, hence the notion of the state elites becoming warlords themselves. The conflict in Burundi is a classic illustration of this point. M. Duffield, Global Governance and the New Wars, p. 15. For further reading on the concept of 'penetration' see Buzan \& Wæver, Regions and Powers, The Structure of International Security, pp. 46-47.

25 K. O'Brien, Military-Advisory Groups and African Security, p. 80.

26 K.J. Holsti, The State, War, and the State of War, pp. 20-21. 
To some extent, therefore, it is possible to reduce the concept of war in International Relations since 1945 to a question of state-maintenance and state failure. ${ }^{27}$ The realist claim that wars will eventually break out in an anarchic system does not stand up to empirical scrutiny. Empirical evidence shows that three regions in the world (Europe, North and South America) have not experienced any local interstate wars for half a century. ${ }^{28}$ This is because of the division of the international system into the two zones in which the dominant states in the so-called developed world do not conduct their affairs according to the same standards as third-world countries. It can be argued that the interstate conflict involving Iraq underlines the fact that conflict still arises as part of the interaction between firstworld and third-world states.

\section{War 'by proxy'}

Nevertheless, in sub-Saharan Africa, the Charter of the OAU placed limits on states acting against other states by military means, thus reducing the possibility of interstate warfare breaking out in sub-Saharan Africa. Interstate war has despite this occurred several times on the continent the latest example being the war between Ethiopia and Eritrea from 1998 - 2000. As previously mentioned interstate war seems to have been replaced intrastate war. However, a new type of war by proxy has emerged. Where interstate disputes are not solved through direct military intervention, as in the case of the conflict in the Democratic Republic of Congo (DRC), but are fought through agents in the target country. One example of this is the Rwandan strategy in the Kivus and the conflicts in the Manu River region. It could be argued that the bi-polar Cold War superpower penetration into sub-Saharan Africa also was a war by proxy, the new war by proxy is dominated by warlords and elitist state leaders using agents in the target states. The conflicts in the Manu River area since the beginning of the 1990 are an excellent case of point. How, then, is present-day interstate warfare to be understood? Although there are still clear examples, is this an indication of an increased use of a technique of subversion, which to some extent must be regarded as a modern type of interstate warfare? This was the case in respect of the relationship between Libya, Chad and the Central African Republic (CAR). While Libya did support Ange Felix Patassé and the rebel movement in Chad, Chad was supporting and accommodating rebels from the CAR. Is this then to be interpreted as an undeclared interstate war being fought by agents of the states involved? There is nothing new about this scenario, which often occurred during the Cold War. However, it could be argued that, since the international community does not accept interstate wars, unresolved issues could

\footnotetext{
$27 \quad$ K.J. Holsti, The State, War, and the State of War, p. 76.
}

$28 \quad$ K.J. Holsti, The State, War, and the State of War, p. 25. 
only be solved by proxy. The situation in the DRC tells another story, unless this is to be interpreted as a case where both scenarios may be at work at the same time.

\section{Sovereignty as concept and failed states in sub-Saharan Africa}

\section{'Sovereign is he who decides over exceptional circumstances ${ }^{29}$}

The end of the Cold War had offered some kind of hope to sub-Saharan Africa because it resulted in an immediate withdrawal of super-power support for some of the major antagonists on the continent. Thus the regimes in Somalia, Ethiopia and Liberia collapsed, and negotiated settlements were reached in Namibia, South Africa and Mozambique. However, this withdrawal of support also left a number of African states extremely vulnerable to destabilisation, and the traditional patronage networks often could not be sustained. Combined with the devastating effects of the 1980s debt crisis and SAPs, post-colonial states in sub-Saharan Africa generally became increasingly vulnerable, teetering on the verge of collapse, as in Somalia and Liberia. One of the problems faced by African states was a lack of leadership. To use Clapham's metaphor, the ship's captains, that is, certain dominant political leaders, could not spend time setting a course and navigating, but had to concentrate on staying afloat. ${ }^{30}$ This left several African states exposed and vulnerable to destabilisation. One characteristic of these failing states has been that the closer their relationships with world economic markets have become, the closer have they moved to becoming warlords ${ }^{31}$ - in other words, the rulers of the failing African states have tended to become warlords themselves. Indeed, warlords have filled the security vacuum left by the major powers in the aftermath of the Cold War. However, a new generation of political leaders emerged after the end of the Cold War initiating political and economic reforms that have started to transform the continent. Still, there is no progress without setbacks, and the wars in the great lakes, the crisis in Zimbabwe, the disappointment in Zambia and the continued conflict in the Manu River area indicate that even though developments on the continent have been generally positive, there is still a long way to go. ${ }^{32}$

29 C. Schmitt, 'Definitionen af suverænitet', Kritik 150/2000, pp. 39-50.

30 C. Clapham, Africa and the International System, p. 5.

According to Crawford Young, the rise of warlords and private militias in the 1990s was due to members of the armed forces moving into the densely populated rural areas after losing power. This meant a proliferation of small arms and personnel into the rural areas, the state lacked the coercive means to counter this tendency. For a further reading of the concept of warlordism, see W. Reno, Warlord Politics and African States.

32 However, it is important to recognise that democratic reform does not necessarily ensure stability. In a number of instances, indeed, it has led to increased instability, especially in states with insufficient security structures. Nigeria could be seen as example of this where the introduction of multiparty democracy seems to have 
The lack of empirical statehood indicates that the citizens of a state are being deprived of access to the basic public services that are traditionally associated with independent statehood. ${ }^{33}$ Governments of this type in often failed states frequently lack the political capacity to exercise institutional authority, for example, the coercive power to secure human rights and socio-economic welfare, that is, the security of the individual citizen in broad terms. The privileges of sovereign statehood are often the preserve of narrow elites and are not extended to the citizen body generally. Sovereignty in this article is understood as an authority to rule over a specific territory and the citizens who live within it, and not just as a state decides for itself how it will deal with its internal and external problems. ${ }^{34}$ These states are thus primarily of a judicial nature and are therefore called 'quasi states'. ${ }^{35}$ For a whole range of sub-Saharan African political leaders, the source of their legitimacy stems from the international recognition of the judicial state. As Clapham argues, the principles of judicial statehood, however defensible they may have appeared to be, thus came to shape the international relations of fragile states in ways which eventually undermined the very goals of global peace and order which they had been intended to foster. ${ }^{36}$ However, Mohammed Ayoob argues that the change in the concept of sovereignty have a negative effect on international society. The African states are in a process of state formation and should to a certain extent be left alone, even when the leaders are using force. It is according to Ayoob no different from what both the Europeans and the Americans did during their state-building phase. ${ }^{37}$

During the Cold War the states of Eastern Europe had, despite their formal status as independent units, a de facto limited sovereignty because of the ultimate control exerted by the Soviet Union. The same can be said about American influence over Central America until the $1960 \mathrm{~s} .{ }^{38}$ Furthermore, in the case of sub-Saharan Africa, domestic legitimacy, and therefore domestic sovereignty, is often nonexistent and the elites manage their relationships with the wider public via economic transactions. This means that the dualism, which the concept sovereignty implies, that is both domestic and external accepted authority, might be lacking. In a number of sub-Saharan African states the domestic authority is lacking and there might be several actors competing for the same right to authority. This is also why the members of the OAU, and other actors for that matter, have historically been so

increased the tension between the different ethnic and religious groups. Zimbabwe, Zambia and Malawi could be other examples of a similar dynamic.

R. Jackson, Quasi States, p. 21.

M. Ayoob, Humanitarian Intervention and State Sovereignty, p. 82.

R. Jackson, Quasi States for further reading on this concept.

C. Clapham, Africa and the International System, p. 19.

M. Ayoob, Humanitarian Intervention and State Sovereignty, p. 94.

B. Buzan, People, States and Fear, p. 68. 
reluctant to support separatist movements. Their fear has been that a dangerous precedent might be created that could be used against themselves. In the OAU Charter, the resolution concerning the inviolability of frontiers of 1964 states:

'Considering further that the borders of African states, on the day of their independence, constitute a tangible reality. ${ }^{39}$

The recognition granted to judicial statehood as a term in the OAU Charter is one of the clearest ever made. The recognition of the inviolability of borders became the central element in the history of the organisation. ${ }^{40}$ This has resulted in the existing boundaries becoming the raison d'être for the state. ${ }^{41}$ Maintaining these boundaries has been the primary concern of sub-Saharan African ruling elites, that is, politicians, the military, bureaucrats and intellectuals. There has been widespread consensus over this throughout the continent because the situation was much the same for everybody. ${ }^{42}$ For the elites the state was central because it ensured the preservation of the institutional entity and, with it, the elites' control over power and the state. It is interesting to notice that there seems to be a tendency where the NonAligned Movement's members generally tend to hold fiercely unto the right to national sovereignty, whereas in the developed world there has been a movement towards the introduction of other elements that overrule national sovereignty of weak authoritarian rulers outside the 'liberal zone'. As argued by Ayoob, power is not equally distributed in the world, and sovereignty therefore becomes an important tool for the weaker actors in their relations with the stronger actors in the international system. ${ }^{44}$

3

40

41

42

43

44

OAU, Resolution on the Intangibility of Frontiers, AGH/RES. 16(I), Cairo July 1964. C. Clapham, Africa and the International System, p. 110.

A good illustration of the uncertainty that surrounds the African State is a quotation by the former president of Tanzania, Julius Nyerere: 'My greatest success is also my greatest disappointment. We have established a nation - Tanzania - that is some achievement. Stable, united, proud, with immense clarity of what it wants to do, committed to the liberation of our continent. It has played an immense role-poor as it is - in the liberation of our continent, and it will continue playing it. So that is what I think is our greatest achievement. But also our failure. I never wanted a Tanzania. I really did not believe that these African countries should establish different sovereignties. They are artificial creations, all of them', Quotation from Multiparty Democracy in Tanzania, in P. Ahluwalia \& A. Zegeye, p. 35.

C. Clapham, Rethinking African States, p. 9.

However no rule without exceptions and in the case of for instance the war in Biafra from 1967-70 several OAU members chose to recognise the independence of Biafra.

M. Ayoob, Humanitarian Intervention and State Sovereignty, p. 84. 


\section{The relationship between 'state' and 'state sovereignty'}

The state is both a metaphysical idea in the minds of the people and an institutional structure and concept, that is, an actual territory. ${ }^{45}$ This means that the idea of the state is not enough in itself, because it implies that nations without territories are states, which is not the case. However, territories that lack the idea of the state may be de facto sovereign states under international law, even though they might not function as such. 'Sovereign' in this article means that the state decides for itself how it will deal with its internal and external problems, including whether or not to seek assistance from others and in doing so to limit its freedom by making commitments to them. ${ }^{46}$

Barry Buzan argues that states without the idea of domestic sovereignty will have difficulties in surviving in the longer term. ${ }^{47}$ However, what kind of timeframe can be used to determine what kind of state will survive or not? His argument seems to have evolved around the concept that elitist minority regimes without the necessary domestic legitimacy will eventually collapse, because the majority of the population has been excluded from participating in society. Nevertheless, true though this might be, the concept and idea of statehood might change over time. Moreover, because the concept is merely an institutional historical construct, the idea of the state will change with it when the reason for the state changes. Basically the concept of state refers to a specific way of organising a societal group, whether it is to be considered primitive or modern. Some kind of social and political organisation always takes place whether we name it state or not. ${ }^{48}$ Historically the concept of the state has changed several times from, for instance, the princely state to nation state. Some state units have survived while others have not, and most states change in size and nature. Buzan's concept carries with it the danger of seeing the contemporary idea of the state as the final point on a continuum of state development. It can be argued that, at the end of the twentieth century, the concept of the state faced severe challenges, which underlines the fact that the understanding of the concept of the state today might only be part of a wider developmental project.

The principle of non-intervention, and thereby the principle of sovereignty as being the single most important feature in international relations, in the domestic affairs of another sovereign state dates back to the Peace of Westphalia in 1648. It

B. Buzan, People, States and Fear, p. 64.

K. Waltz, Theory of International Politics, p. 96.

B. Buzan, People, States and Fear, p. 78.

Lecturer given by Professor Lars Bo Kaspersen, at the Vital Matters Conference in Bergen, Norway, 21 February 2004. 
was an attempt to create order in the anarchic international system, which at the time was in reality restricted to Europe. As part of the colonial powers imperial projects the Westphalian system was expanded to other part of the world, and became the dominant system. However, the concept of sovereignty was derived from the idea that certain territories and peoples were the property or patrimony of the ruler. ${ }^{49}$ The question of sovereignty has therefore formed the basis for a state's right to selfdetermination within the framework of its territorial borders. However, a state's 'sovereignty' is only valuable if it is accepted by the other states in the international system. In legal-political terms, sovereignty is therefore defined as a characteristic of the state in international law and entails the international recognition accorded to a state by other states - this being the sole source of legitimate power within its territory - and it being independent of control and interference from any other state in the conduct of its international relations. ${ }^{50}$ This is what the German philosopher Georg W.F. Hegel meant when he argued that a state only becomes a state when it appears as such in a social relationship with another state. It is precisely at the moment, when two or more states are interacting, that they constitute each other as states. $^{51}$

The correlation between territorial control and sovereignty is central because the boundaries of the territory define the distinction between citizenship and noncitizenship, that is, between them and us. According to Schoeman, it is nationality and citizenship that form the bond that unites people within a fixed, demarcated space called a territory, where people form a collective identity through a sense of belonging to this imagined community. Nevertheless, the correlation between international recognition and de facto control of a state is central to international law. For instance, although most international states during the end of the 1990's did not recognise the legitimacy of the Islamist Taliban regime in Afghanistan, it was in de facto control of the majority of Afghan territory and was therefore entitled to protection and rights under international law. The only way around this would have been for the international community to recognise another party to the conflict as a legitimate government, for instance the Northern Alliance. Even though sovereignty and physical territory have become characteristic of the modern state, Joseph Kabila's situation in the DRC after the assassination of his father in January 2001 can be seen as an example of how a sovereign national leader may lose most of his domestic sovereignty, because he is dependent on foreign military assistance for his

H. Bull, The Anarchical Society, p. 19.

M. Schoeman, Building a Secure Community in Southern Africa, p. 47.

L.B. Kaspersen, The Transformation of the State in Western Europe: Towards a New Struggle of Recognition', p. 5. 
control over the government of his country. ${ }^{52}$ However, in the case of the DRC it can be argued that though the late President Mobuto managed to create an idea of state, that is the concept of 'Congo uni', the rulers domestic authority has since independence at all times been weak. The success of the state accordingly depends on the preservation, or the creation of the domestic community. The central authorities, therefore, must be in a position to provide the necessary structures for the society to function properly. A breakdown of the state's capacity to provide for its citizens will also mean a breakdown of its sovereignty. Put simply, it will cease to exist. In contrast to the judicial understanding of the term 'sovereignty', the political dimension focuses on the ability of actors to act. Sovereignty is therefore correlated closely with the capacity of government to rule. One connotation of the term is that it consists of bundles of powers that may grow larger or smaller.

\section{Intervention and state failure}

As noted above, the contemporary international system is based on a system of sovereign states in which non-intervention has been the norm until recently and every intervention must be justified by the forces doing so. For instance, Article 4 of the Constitutive Act of the African Union (AU) enjoins:

'Non-interference by any Member State in the internal affairs of another' [and] the right of the Union to intervene in a Member State pursuant to a decision of the Assembly in respect of grave circumstances, namely: war-crimes, genocide and crimes against humanity ${ }^{, 53}$

Intervention in its legal meaning is 'interference with matters within the exclusive jurisdiction of a subject of international law and, unless justified by a specific rule to the opposite effect, constitutes an illegal act. ${ }^{54}$ Intervention must further more be divided into 'coercive military intervention' and 'coercive nonmilitary interventions', for instance sanctions. ${ }^{55}$ Article 4 of the Constitutive Act of the AU and Article 2 of the UN Charter stresses that the concept of sovereignty was never intended to be without limits, for example, sovereignty as a concept cannot legitimise a state committing genocide within its own boundaries. The Constitutive Act of the AU goes even further by opening the possibility for the union to intervene in grave circumstances. It can be argued that an unlimited understanding of the concept developed during the Cold War in particular, where the notion of sovereignty was (mis-)used as a bargaining chip in the power struggle between the

R. Lemarchand, The Democratic Republic of Congo, p. 41.

African Union, Constitutive Act, Article 4.

G. Schwarzenberger and E.D. Brown, A Manual of International Law, p. 228.

See H. Shue, 'Limiting Sovereignty', in J.M. Welsh ed., Humanitarian Intervention and International Relations. 
antagonists in the bi-polar world order. ${ }^{56}$ The fight for power in Angola following the collapse of the Alvor agreement in 1975 in the run-up to independence illustrates this point. The question of sovereignty formed the basis of the state's right to selfdetermination within the framework of its territorial boundaries, as underlined in UN resolution 1514. ${ }^{57}$ The problem with resolution 1514 was that, while in the Angola case it recognised the right to self-determination, it also caused the collapse of the empirical state as the defining concept of sovereignty. In legal-political terms, once again, sovereignty is defined as a characteristic of the state in international law and refers to the international recognition accorded a state by other states. This includes a recognition that it is the sole source of the legitimate exercise of power within its territory and is independent of control or interference from any other state in conducting its international relations. ${ }^{58}$ However, rules are defined not only in terms of international law, but also as principles, standards, conventions and practices. ${ }^{59}$ International law evolves and changes through violations of existing practice that later achieve broad recognition as legitimate. ${ }^{60}$

\section{Sovereignty and the new humanitarianism}

At the end of the Cold War, the concept of sovereignty came under pressure because the international community became increasingly aware of humanitarian issues. Intervention on 'humanitarian grounds' became an issue because the international community was faced with ethnic cleansing and massacres in both subSaharan Africa and the former Republic of Yugoslavia. However, the basis whereby the principle can be used to overrule state sovereignty has been a matter of fierce debate. A number of states with substantial ethnic and religious minorities have rejected this new humanitarianism, because of a fear of foreign interference in what has traditionally been perceived as falling under the jurisdiction of the sovereign state. Up to now, therefore, it has been impossible for the international community to agree on a mandate strictly on humanitarian grounds. Thus, mandates have been given for other reasons, mainly because of a threat to international peace and stability. It could be argued that the apparently increasing international acceptance,

56 H. Shue, 'Limiting Sovereignty', pp. 14f, in J.M. Welsh ed., Humanitarian Intervention and International Relations.

57 Resolution 1514 from 1960 has historical been celebrated as the signal that secured the former colony's independence and it was stated in the resolution that: 'All peoples have the right to self-determination' and 'Inadequacy of political, economic, social or educational preparedness should never serve as a pretext for delaying independence'; see UN Resolution 1514 (XV), 947 ${ }^{\text {th }}$ plenary meeting, 14 December 1960.

$58 \quad$ Daninh Institute of International Affairs, Humanitarian Intervention, p. 47.

59 R. Jackson, Quasi States, p. 3. See also G. Schwarzenberger and E.D. Brown, A Manual of International Law, pp. 33-36.

60 I thank Professor of Law Isi Foighel for pointing this out to me. 
in the 1990s of the German Philosopher Immanuel Kant's concept of a 'community of men' taking priority over a 'community of states', has had a tremendous impact on how the international community is perceived and organised. This means that the security and life of the individual human being is perceived to be more important that the security of the individual state. The individual is essentially free and a 'sovereign' over his/her own life, before being member of a political community.

This has led to an undermining of the term 'sovereignty', or, more precisely, the term is now being used selectively with regard to the 'level' of legitimacy of individual states. ${ }^{61}$ It can also be argued that the concept of sovereignty changed during the 1990s from being a matter of authority to one of invoking responsibility. ${ }^{62}$ The contemporary community of states is partly the result of the existence of authoritarian states that fear the idea of a community of men, since this would result in a reduced significance for the concept of sovereignty. However, this is also the result of the development of the concept of the liberal peace model or of democracy by force. ${ }^{63} 64$

The first world-based historical distinction between civilised and barbarian states must be understood within this framework. ${ }^{65}$ The notion of civilisation mainly implies refraining from the arbitrary use of force and obeying the rule of law, which forbids it. A civilisation descends into barbarity unless it treats every individual member of the group as humanely as possible. ${ }^{66}$ To be recognised as 'civil,' a state must act in a 'civil' manner, that is, conform to international standards and norms as set out by the dominant states. In the 1990s, a failure to comply with the 'public law' of mankind was used to legitimise certain interventions, as in Kosovo, Afghanistan and recently Iraq. It should also be stressed that in the post-September 11 world order and the general war on terror, a sovereign's inability to control a particular territory may result in an intervention, because of the perceived risk to international peace and security. American President George W. Bush's singling out of certain international states as being 'rogue' states and 'an axis of evil', and therefore a threat

\footnotetext{
61 Danish Institute of International Affairs, Humanitarian Intervention, p. 17.

J.M. Welsh, Humanitarian Interventions and International Relations, p. 2. For further reading, see K. von Hippel, Democracy by Force.

It should also be noted that the concept of international law is by no means interpreted in the same way by, for instance, the American and Danish governments. The US government has always claimed that it did not need the blessing of the UN Security Council to launch a military operation, while the Danish government always has claimed allegiance to the international system, that is, the UN. See newspaper article by Professor of Law Ole Esbersen in Politiken, Sunday 15 February 2004.

65 For further reading on this distinction, see, for instance, R. Gilpin, War and Change in World Politics, pp. 114ff.

66 R.G. Collingwood in R. Jackson, Quasi States, p. 142.
} 
to the international order, must be understood within this framework. However, justification, jus a bellum, of the use of 'humanitarian intervention' as a tool in international relations mandated by the UN requires evidence of serious breaches of international law concerning human rights to be produced before intervention in a sovereign state can be mandated without that state's consent. It has, therefore, not yet been possible for the Security Council to agree on a mandate based on humanitarian grounds alone.

It is not stated anywhere in the UN charter that human rights alone, even though they are important, can overrule the sovereignty of the state. Members of the Non-Aligned Movement (NAM) have asserted this fact vigorously, because the authoritarian and elitist third-world countries that are included among its members are those most likely be the targets of this type of intervention. As mentioned earlier, there is also a risk of humanitarianism becoming the 'civilised' world's tool in managing the 'barbarians', that is, the third world, or non-liberal zone, in general. The consequence of this is that the humanitarian tool could very easily come to be seen as a way of challenging the independence of a number of states because they do not fulfil the basic principles and norms set out by the great powers in the international system, that is, they do not conform to the 'liberal peace model'. Put more boldly, this could be seen as an attempt to impose Western lifestyles and political systems upon third-world states. ${ }^{67}$ In discussions over human rights, a similar debate has been going on in which certain third-world leaders have argued that a special form of human rights were invoked in their attempts to legitimise their own human rights violations. It can also be argued that the adoption of the African Charter for Human Rights included so many derogations that it freed the sovereign rulers from the very obligations to protect human rights that it was supposed promote.

In support of the interventionist norm, it could be argued that sovereignty has been used by elitist and repressive regimes to protect their hold on power. It could be argued that, where the main obstacle to the humanitarian approach during the Cold War was the antagonism between the former superpowers, today, at least until the recent trans-Atlantic dispute over Iraq, it is a matter of disagreement between the North and the South. This is not to say that the debate is new, just that such antagonisms used to be overshadowed by rivalry and dominant forms of patronage during the Cold War.

67 It could be argued that in practice the Bush administration is exploiting the Wilsonian idea of making the world safe for democracy by eliminating other forms of government. For further elaboration into the Wilsonian concept. see B. Buzan, People, States and Fear, p. 82. 
Another problem with the humanitarian approach relates to who decides when the level of violations justifies an intervention? How many bodies have to be counted before state sovereignty can legitimately be overruled? One of problems facing the international community is that legitimate national governments, which may well control the capital city but not the necessarily the whole national territory, are often also those responsible for violations committed against its own citizens, Rwanda being an excellent example.

\section{Conclusion: a future perspective}

The lack of internal security in many sub-Saharan African countries has been one of the main threats to stable political and economic development in subSaharan African. The SAPs imposed on third-world countries from the beginning of the 1980 s led to heavy cutbacks in the public sector in the recipient countries, including the security establishments. These states have, therefore, been unable to respond to the increasing internal security pressures that have been witnessed in 1990s. In a number of states the public sector has more or less stopped functioning, including the capacity for coercion, and the patronage networks have declined because of the lack of economic resources, which has severed political ties between patrons and clients or leaders and their subjects. Another consequence of the loss of coercive capacity has been that governments have not been able to fulfil their obligations to provide peace and security for the civilian population, and thus their status as states. The examples of state failures in sub-Saharan Africa - Sierra Leone, Liberia, the DRC and Somalia - are many and frankly extremely worrying. External recognition of post-colonial states is not a problem in itself, because, as has been described above, states are only states if they are recognised as such by others. The problem seems to be a lack of empirical statehood, that is, the lack of a monopoly on the use of coercion, control over territory, bureaucratic and tax-collecting capacity, as well as a reduced acceptance of the state on the part of its own citizens. These empty states have come under international pressure because the dominant actors in this unequal social interaction have begun to demand empirical statehood as a prerequisite for state recognition.

The consequence of sub-Saharan Africa's fragmented states, paralysed state systems, international marginalisation and economic collapse has been the opportunity it offers to international and domestic actors to make use of this power vacuum and create an alternate power base for the accumulation and control of resources. This 'criminalization', to use Jean-François Bayart's term, of postcolonial sub-Saharan African state structures happens in a different historical context than was the case during the earlier state-building process in Europe, for 
example. ${ }^{68}$ In sub-Saharan Africa, different institutions, treaties and concepts have been developed that impose limitations on the concept of state-building. Although the principle of the inviolability of borders was intended to prevent inter-state conflict focusing on the borders themselves, in the 1990s, this simply increased intra-state instability and insecurity. State elites have increasingly sought refuge behind the inviolability of borders and the international recognised sovereignty of their states, these two concepts having increasingly become the major agent of legitimisation. Although empirical statehood is lacking, limited domestic legitimacy of statehood can be found. The DRC could be seen as an example of this, where it seems that the concept and idea of 'Congo Uni' seems to have survived many years of conflict. The idea of the united state exists despite the collapse of the states infrastructure.

Furthermore, Article 4 of the Constitutive Act of the AU is very important, because for the first time it recognises the right of the organisation to intervene without prior consent in the domestic affairs of a member state. These new principles show that AU members are moving towards an acceptance of the principle that a community of men has priority over a community of states. However, the 1990s showed that the international community possesses neither the will nor the capacity to handle military, economic and social emergencies in subSaharan Africa effectively. This might change with the increased European Union concentration on conflict-resolution in sub-Saharan Africa in regard to both capacity-building measures and actual deployments. However, most of the continent is still being left to its own devices, which in the 1990s often meant being left in the hands of powerful warlord rulers allied to dubious Western economic interests. The social and economic consequences for civil populations have often been unbelievable poverty and despair. The AU's plans to create a military stand-by force consisting of 15000 soldiers will, according to the initial plans, not become operational before 2010. Until that date, it seems that the continent will have to rely on coalitions of willing African states to intervene in conflict zones.

However, developments at the turn of the $21^{\text {st }}$ century also showed that different intervention models were being used, depending on the strategic significance of the case in hand. The intervention in Iraq was an example of the military interventionist model, where the goal was regime change, that is, introducing democracy with the use of force. Another interventionist model was the sanction model, used, for instance, in relation to Zimbabwe. In both cases there is a

68 For further reading on the concept of the 'criminalisation of the state' see F-J. Bayart et al, Politics of the Belly, and F-J. Bayart et al, The Criminalisation of the State in Africa. 
North-South divide, though in the case of Iraq what US Defence Secretary Donald Rumsfeld has called a division between the new and the old Europe has also emerged. Nevertheless, the tendency, even in the South, is towards an increasing recognition that the principles of a community of men should come before the idea of a community of states. The historical concept of sovereignty is changing rapidly and assuming a new form. However, as argued by Ayoob, there is a big difference between intervening in states that have ceased to function as states and thereby lost there sovereignty ${ }^{69}$ and claiming that because state agents uses national sovereignty to violate individual human rights, the international community has a right to intervene. $^{70}$

The end of the Cold War and the normative changes that followed during the 1990s point toward a return to some kind of reintroduction of the 'protectorate system'. This means that the international community, dominated by the members of the 'liberal zone', now considers that it has a right to take control of the administration of a specific territory for a period of time if that territory is unable to govern itself, for example through a transitional phase towards independence or following a state collapse. This has been seen since the end of the 1990's in Kosovo, East Timor, Afghanistan and now in Iraq, although the term 'protectorate' has not been used. This means that the international community is also increasingly arrogating the right and duty to declassify states that have ceased to exist or to function as states, as well as states that are refusing to adhere to the liberal peace model. In effect, this means removing recognition of the sovereignty of these territories for the time being. This might happen in the future in sub-Saharan Africa as well, especially in collapsed states like Somalia and Liberia. However, this is not a formal return to the protectorate system, including the UN protectorate system. The reintroduction of this de facto protectorate system must be understood not as a joint decision of the international community, but as a result of the actions of a number of strong states acting on their own, that is primarily the first world states. Law in general, and therefore international law, is influenced by trends in the surrounding world society. The dominant states are slowly changing international law by their actions in enforcing humanitarian actions in the surrounding world, and this process is gradually being accepted by, for instance, the African states, as illustrated by Article 4 of the AU Constitutive Act stipulating the right of the AU members to intervene.

69

As suggested by R. Jackson in his book, The Global Covenant: Human Conduct in a World of States.

For further reading on this see M. Ayoob, Humanitarian Intervention and State Sovereignty. 


\section{Bibliography}

African Union, Constitutive Act of the African Union, Addis Ababa, 2001.

Ahluwalia, Pal \& Zegeye, Adebe. 2001. Multiparty Democracy in Tanzania - Crisis in the Union. African Security Review, vol. 10, no. 3.

Ayoob, Mohammed. 2002. Humanitarian Intervention and State Sovereignty. International Journal of Human Rights, vol. 6, no. 1, Spring.

Bayart, Jean-Francois. 1996. The State in Africa: The Politics of the Belly. Longman: London \& New York, $3^{\text {rd }}$ edition.

Bayart, Jean-Francois; Ellis, Stephen \& Hibou, Béatrice. 1999. The Criminalization of the State in Africa. International African Institute in cooperation with James Currey and Indiana University Press: Oxford

Berdal, Mats R. 1993. Whither UN Peacekeeping? Adelphi Paper, 281, October.

Bull, Hedley. 2002. The Anarchical Society: A Study of Order in World Politics. Palgrave: Basingstoke. $3^{\text {rd }}$ edition.

Buzan, Barry. 1991. People, States \& Fear. Harvester Wheatsheaf: New York and London.

Buzan, Barry. 2004. From International to World Society. Cambridge Studies in International Relations: 95, Cambridge University Press: Cambridge.

Buzan, Barry; Jones, Charles \& Little, Richard. 1993. The Logic of Anarchy, Neorealism to Structural Realism. Columbia University Press: New York.

Buzan, Barry \& Wæver, Ole. 2003. Regions and Powers; The Structure of International Security. Cambridge Studies in International Relations: 91, Cambridge University Press: Cambridge.

Chabal, Patrick \& Daloz, Jean-Pascal. 1999. Africa Works: Disorder as Political Instrument. International African Institute, in cooperation with James Currey and Indiana University Press: Oxford and Bloomington.

Chazan, Naomi; Mortimer, Robert; Ravenhill, John \& Rothchild, Donald. 1992. Politics and Society in Contemporary Africa. Lynne Rienner: Boulder, Colorado. $2^{\text {nd }}$ edition. 
Cilliers, Jakkie \& Mason, Peggy, (eds). 1999. Peace, Profit or Plunder? The Privatisation of Security in War-Thorn African Societies. Institute for Security Studies: Pretoria.

Cilliers, Jakkie \& Mills, Greg, (eds). 1999. From Peacekeeping to Complex Emergencies: Peace Support Missions in Africa. SA Institute of International Affairs and Institute for Security Studies: Johannesburg.

Clapham, Christopher. 1996. Africa and the International System. Cambridge University Press: Cambridge.

Danish Institute of International Affairs. 1999. Humanitarian Intervention. Dansk Udenrigspolitisk Institut: Skjern.

Du Plessis, Louis \& Hough, Michael, (eds). 2000. Managing African Conflicts: The Challenge of Military Intervention. HSRC Publishers, Pretoria.

Duffield, Mark. 2001. Global Governance and the New Wars: The Merging of Development and Security. Zed Books: London \& New York.

Danish Foreign Policy Institute 1999. Humanitarian Intervention. Dansk Udenrigspolitisk Institut: Skjern.

Findlay, Trevor. 2002. The Use of Force in UN Peace Operations. SIPRI in cooperation with Oxford University Press: Oxford.

Furley, Oliver and May, Roy, (eds). 1998. Peacekeeping in Africa. Ashgate: Aldershot.

Gilpin, Robert. 1981. War \& Change in World Politics. Cambridge University Press: Cambridge.

Holsti, Kalevi J. 1996. The State, War, and the State of War. Cambridge University Press: Cambridge.

Jackson, Robert. 2000. The Global Covenant: Human Conduct in a World of States. Oxford University Press: Oxford.

Jackson, Robert. 1993. Quasi-States: Sovereignty, International Relations, and the Third World. Cambridge University Press: Cambridge.

Kaspersen, Lars Bo. 2004. The Transformation of the State in Western Europe: Towards a New Struggle of Recognition. Paper presented at a conference on War and State, Bergen, Norway, 21-22 February. 
Lemarchand, René. 2001. The Democratic Republic of Congo: From Collapse to Potential Reconstruction. Centre of African Studies Occasional Paper. University of Copenhagen, 16 September.

Møller, Bjørn. 2001. Private militære virksomheder og fredsoperationer i Afrika. COPRI Working Papers, 13/2001.

Neethling, Theo. 1998. Maintaining International Peace and Security: Reflections on Peace-Support Operations in Africa. Scientia Militaria, vol. 28, no. 1, 1998.

Neethling, Theo, 1999. Peacekeeping in Africa: Reflections on developments and trends, Koers, vol. 64, no. 4, 1999.

O'Brien, Kevin. 1998. Military-Advisory Groups and African Security: Privatized Peacekeeping? International Peacekeeping, vol. 5, no. 3.

Organisation of African Unity (OAU). 1964. Resolution on the Intangibility of Frontiers, AGH/RES, 16(I), Cairo, July.

Reno, William. 1998. Warlord Politics and African States. Lynne Rienner: London.

Schmitt, Carl. 2000. Definitionen af suverænitet, Kritik, 150/2000.

Schoeman, Maxi. 1998. Building a Secure Community in Southern Africa: The Case of SADC. Unpublished PhD dissertation, University of Wales. Aberystwyth.

Schwarzenberger, George and Brown, E. D., 1976. An Annual of International Law. Professional Books Limited: Milton.

Shearer, David. 1998. Private Armies and Military Intervention. Adelphi Paper, 316. Oxford

Spruyt, Hendrik. 1994. The Sovereign State and its Competitors. Princeton University Press: Princeton.

Sørensen, Georg. 2002. The Global Polity and Changes in Statehood, in Ougaard, Morten and Higgott, Richard, (eds), Toward a Global Polity,. Routledge: London \& New York.

Tilly, Charles. 1985. War Making and State Making as Organized Crime, in Evans, Peter B., Rueschemeyer, Dietrich and Skocpol, Theda, (eds), Bringing the State Back In. Cambridge University Press: Cambridge.

United Nations (UN). 1945. Charter of the United Nations. United Nations: New York. 
United Nations (UN). 2000. Report of the Panel on United Nations Peace Operations. United Nations: New York.

United Nations (UN). 1998. Report of the Secretary-General: The Causes of Conflict and the Promotion of Durable Peace and Sustainable Development in Africa. United Nations: New York.

Von Clausewitz, Carl. 1982. On War. Penguin Books: London. $3^{\text {rd }}$ edition.

Von Hippel, Karin. 2000. Democracy by Force: US Military Intervention in the Post-Cold War World. Cambridge University Press: Cambridge.

Wallensteen, Peter \& Sollenberg, Margareta. 2001. Armed Conflict, 1989-2000, Journal of Peace Research, vol. 38, no. 5, September.

Waltz, Kenneth. 1979. Theory of International Politics. McGraw-Hill: New York.

Weiss, Thomas G., (eds). 1998. Beyond UN Subcontracting: - Task Sharing with Regional Security Arrangements and Service - Providing NGOs. International Political Economy Series. Macmillan Press: London.

Welsh, Jennifer M., (eds). 2003. Humanitarian Intervention and International Relations. Oxford University Press: Oxford. 